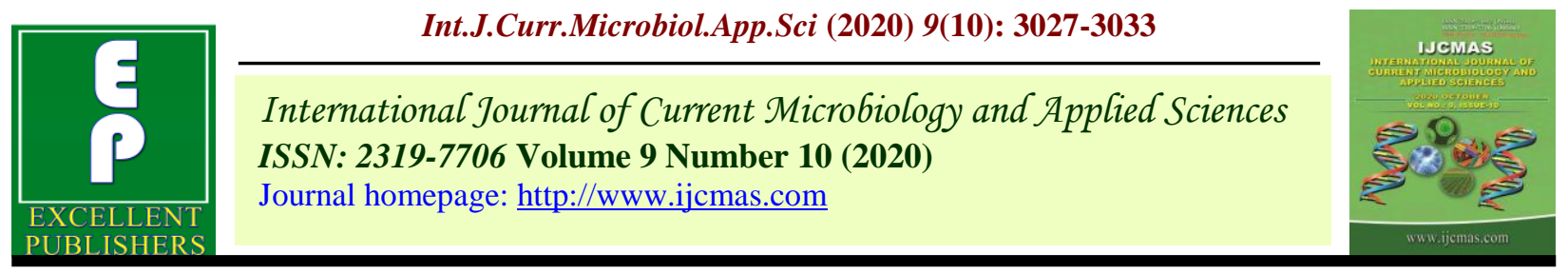

Original Research Article

https://doi.org/10.20546/ijcmas.2020.910.364

\title{
Utilization Pattern of Pesticides by Rice Growers in Thoubal District, Manipur, India
}

\author{
Arnold Meitankeisangbam ${ }^{1}$, Aheibam Tarajit Singh $^{2}$ and Changamayum Girija Devi ${ }^{3}$ \\ ${ }^{1}$ Pandit Deen Dayal Upadhyay Institute of Agricultural Sciences, \\ Utlou, Bishnupur, Manipur, India \\ ${ }^{2}$ KVK Utlou, Bishnupur, Manipur \\ ${ }^{3}$ Manipur University, Canchipur, Manipur, India \\ *Corresponding author
}

\section{A B S T R A C T}

\begin{tabular}{|l|} 
Keyw or d s \\
Pesticides, \\
Utilization pattern, \\
Rice growers, \\
Manipur \\
\hline Article Info \\
\hline $\begin{array}{l}\text { Accepted: } \\
\text { 24 September } 2020 \\
\text { Available Online: } \\
\text { 10 October } 2020\end{array}$ \\
\hline
\end{tabular}

\begin{abstract}
Manipur is one of the leading rice producing state. With the increase of the population, the requirement and demand of all crops has been tremendously increased. The role of pesticides has become critically important with modernization of agriculture. The present study has been undertaken about utilization pattern of pesticides by rice growers in Thoubal district, Manipur. The present study was conducted in Thoubal sub-division of Thoubal district, Manipur. 120 respondents were randomly selected for the study. The study revealed that majority of respondents i.e. 55.00 percent used two-three insecticides along with the fungicides and 63.33 percent used systemic + contact pesticides. The study also found that Pyrazosulfuron ethyl, Chlorantraniliprole and Carbendazim was ranked first among the herbicides, insecticides and fungicides respectively by the respondents.
\end{abstract}

\section{Introduction}

Rice (Oryza sativa) is among the three leading food crops of the world with maize and wheat being the other two. India has the largest area under rice cultivation, as it is one of the principal food crops. India is one of the leading exporters of rice in the world. West Bengal is the highest rice producing state in India with a total rice production of 14.97 Million Tonnes with a yield of 2926 kilograms per hectare in the year 2017-18 followed by Punjab, UP, AP, Bihar and Tamil Nadu (Agricultural Statistics at a Glance
2018). Among the North-Eastern states of India, Manipur is also one of the leading rice producing state owing to its salubrious climate and soil type. Agriculture sector contributes a major share to the total state domestic product and also provides employment to about 22.13 per cent (census 2011) of the total workers in Manipur. Out of the total geographical area of the state, only 7.41 per cent is used for cultivation. Of this total cultivated area, $52 \%$ is confined to the valley. Rice is the staple food and is grown in hill and plain areas and it accounts for about $97.7 \%$ of the total foodgrain production of 
the State in the year 2016-17. The rice production in 2016-17 is estimated as 4.93 lakh tonnes which is more than the preceding year's rice output of 4.33 lakh tonnes (Economic Survey Manipur 2017-18). In Manipur, rice cultivation dominates all others crops. With the increase of the population, the requirement and demand of all crops has been tremendously increased. However, the production of the crops has been decreased. The role of pesticides has become critically important with modernization of agriculture. In India, $76 \%$ of the pesticide used is insecticide while, $44 \%$ is used globally. Tremendous benefits have been derived from the use of pesticides in agriculture, which is an important sector upon which the Indian economy is largely dependent. In Manipur, rice is cultivated in almost all the sixteen districts of the state. Thoubal district is one of the leading rice producing districts in the state. In order to increase the rice production in the state, chemical fertilizers play an important role particularly when used with the high yielding varieties which are responsive to recommended doses of fertilizers to meet the requirement of people. Many of the farmers had faced the problems regarding poor knowledge in terms of pesticides doses, nature of chemicals, application details, etc. due to the lack of knowledge or illiterate. To overcome this problem the present study has been undertaken about utilization pattern of pesticides by rice growers in Thoubal district, Manipur.

\section{Materials and Methods}

The present study was conducted in Thoubal district, Manipur during the financial year 2018-19. Thoubal district was selected purposively for the study as the valley accounts for the highest consumption of pesticides for the rice cultivation. Among the sub division of Thoubal district, Thoubal sub division was randomly selected for the study.
Again, ten villages from this sub-division were selected based on farmer's availability and ease of communication. Total sample size of the study was 120 and from each village 10 per cent of the total people engaged in rice cultivation were interviewed randomly. Primary data was collected with the help of pre-tested semi-structured schedules. The data collected from the respondents were scored, tabulated and analysed by using appropriate statistical tools i.e., Mean, frequency, percentage and standard deviation.

\section{Details of statistical techniques used}

\section{Mean}

Mean was calculated by summing all respondent's score and dividing it by number of respondents. It was given as follows

$\bar{X}=\frac{\sum X_{i}}{n}$

Where,

$\bar{X}$ =Mean

$\sum X_{i}=$ Sum of respondents score

$\mathrm{n}=$ No. of respondents

\section{Frequency and percentage}

The frequencies and percentage of respondents were worked out for comparison

\section{Standard deviation}

It is a measure of variability calculated around mean.

$S D=\sqrt{\frac{\sum\left(X_{i}-\bar{X}\right)^{2}}{n}}$

Where,

$\mathrm{X}_{\mathrm{i}}=$ Score of respondents 
$\bar{X}=$ Mean

$\mathrm{n}=$ Number of respondents

\section{Results and Discussion}

\section{Socio-personal profile of the rice growers}

From Table 1 it was revealed that 69.17 percent of respondents belong to the middle age group i.e. age group of 35 to 55 years followed by 15.83 per cent of them belonged to young age group i.e., upto 34 years and 15 percent of the respondents belonged to the old age group i.e., above 55 years of age. Similar finding was also reported by Zore et al., (2017). For education 46.67 per cent of respondents had received graduation, 20.00 per cent respondents received higher secondary education, 18.33 per cent respondents received high school education, 6.67 percent respondents received middle school, 3.33 per cent respondents received primary education and 2.50 per cent of respondents received education of post graduate and above. However 2.50 per cent of respondents can read and write but none of them were illiterate and can read only. In case of size of family it was observed that majority of the respondent i.e., 62.50 per cent of the respondents had medium family size that is between 5 to 7 members in a family, followed by 31.67 per cent of them had small family size that is up to 4 members while 5.83 per cent of the respondents had large family size that is 8 members and above in a family. Similar finding was also reported by Iwuchukwu et al., (2017). For the size of land holdings it was observed that 55.00 percent of the respondents had small size of land holding that is up to 1.00 ha, followed by 35.83 percent of the respondents had medium size of land holding that is 1.01 to 2.00 ha, while 9.17 percent of the respondents had large size of land holding that is above 2.00 ha. In case of social participation it was revealed that 56.67 percent of the respondents had no social participation, followed by 29.17 percent respondents were member of one organization and 14.16 percent respondents were member of two or more organizations. None of the respondents were office bearer of any organization and wide public leader. For the level of source of information it was revealed that 62.50 percent of the respondent were using medium sources of information followed by 19.17 percent of the respondent used low sources and 18.33 percent used high sources of information. For the area under rice cultivation it was evident that $88.33 \%$ of the respondent had medium area under rice cultivation, followed by $7.50 \%$ of the respondent had large area under rice cultivation, while $4.17 \%$ of the respondent had small area under rice cultivation. It was also observed that a majority $(85.00 \%)$ of the respondents had medium annual income followed by high annual income respondents $(13.33 \%)$, whereas only $(1.67 \%)$ of them had low annual income. Also, it was evident that 51.67 percent of the respondents belonged to medium risk orientation category, 42.50 percent respondents belonged to low risk orientation category and 5.83 percent respondents belonged to high risk category.

\section{Utilization pattern of pesticides by the rice growers}

It was observed from Table 2 that 55.00 percent respondents used two-three insecticides along with the fungicides, 24.17 percent respondents used no combination while 20.83 percent respondents used combination of any two pesticides. From Table 3 it was observed that 63.33 percent of the respondents used systemic + contact pesticides, followed by 25.83 per cent respondents used systemic pesticides and 10.84 per cent of respondents used contact pesticides. Similar finding was also reported by Landage (2015). 
Table.1 Socio-personal profile of the rice growers

\begin{tabular}{|c|c|c|c|c|c|c|}
\hline Sl. No. & & Category & Frequency & Percentage & Mean & S.D \\
\hline 1. & Age & $\begin{array}{l}\text { Young (upto } 34 \text { years) } \\
\text { Middle ( } 35 \text { to } 55 \text { years) } \\
\text { Old (Above } 55 \text { years) }\end{array}$ & $\begin{array}{l}19 \\
83 \\
18\end{array}$ & $\begin{array}{l}15.83 \\
69.17 \\
15.00\end{array}$ & 44.65 & 10.33 \\
\hline 2 & Education & $\begin{array}{l}\text { Illiterate } \\
\text { Can read only } \\
\text { Can read and write } \\
\text { Primary } \\
\text { Middle school } \\
\text { High school } \\
\text { Higher secondary } \\
\text { Graduate } \\
\text { Post graduate and above }\end{array}$ & $\begin{array}{l}0 \\
0 \\
3 \\
4 \\
8 \\
22 \\
24 \\
56 \\
3\end{array}$ & $\begin{array}{l}0 \\
0 \\
2.50 \\
3.33 \\
6.67 \\
18.33 \\
20.00 \\
46.67 \\
2.50\end{array}$ & & \\
\hline 3 & Family size & $\begin{array}{l}\text { Small (upto } 4 \text { members) } \\
\text { Medium ( } 5 \text { to } 7 \\
\text { members) } \\
\text { Large ( } 8 \text { and above } \\
\text { members) }\end{array}$ & $\begin{array}{l}38 \\
75 \\
7\end{array}$ & $\begin{array}{l}31.67 \\
62.50 \\
5.83\end{array}$ & 5.17 & 1.42 \\
\hline 4 & $\begin{array}{l}\text { Size of land } \\
\text { holding }\end{array}$ & $\begin{array}{l}\text { Small ( upto } 1.00 \mathrm{ha}) \\
\text { Medium (1.01 to } 2.00 \mathrm{ha}) \\
\text { Large (Above } 2.00 \mathrm{ha})\end{array}$ & $\begin{array}{l}66 \\
43 \\
11\end{array}$ & $\begin{array}{l}55.00 \\
35.83 \\
9.17\end{array}$ & & \\
\hline 5 & $\begin{array}{l}\text { Social } \\
\text { participation }\end{array}$ & $\begin{array}{l}\text { None } \\
\text { Member of one } \\
\text { organization } \\
\text { Member of two or more } \\
\text { organization } \\
\text { Office bearer of any } \\
\text { organization } \\
\text { Wide public leader }\end{array}$ & $\begin{array}{l}68 \\
35 \\
17 \\
0 \\
0 \\
0\end{array}$ & $\begin{array}{l}56.67 \\
29.17 \\
14.16 \\
0 \\
0\end{array}$ & & \\
\hline 6 & $\begin{array}{l}\text { Level of } \\
\text { source of } \\
\text { information }\end{array}$ & $\begin{array}{l}\text { Low (upto } 12 \text { score) } \\
\text { Medium (13 to } 23 \text { score) } \\
\text { High (Above } 23 \text { score) }\end{array}$ & $\begin{array}{l}23 \\
75 \\
22\end{array}$ & $\begin{array}{l}19.17 \\
62.50 \\
18.33\end{array}$ & 17.85 & 5.54 \\
\hline 7 & $\begin{array}{l}\text { Area under } \\
\text { rice } \\
\text { cultivation }\end{array}$ & $\begin{array}{l}\text { Small ( upto } 0.18 \text { ha) } \\
\text { Medium (0.19 to } 1.32 \text { ha) } \\
\text { Large (Above } 1.32 \text { ha) }\end{array}$ & $\begin{array}{l}5 \\
106 \\
9\end{array}$ & $\begin{array}{l}4.17 \\
88.33 \\
7.50\end{array}$ & 0.75 & 0.57 \\
\hline 8 & $\begin{array}{l}\text { Annual } \\
\text { income }\end{array}$ & $\begin{array}{l}\text { Low ( upto Rs. 14,000) } \\
\text { Medium (Rs. 14,001 to } \\
1,07,000 \text { ) } \\
\text { High (Above Rs. } \\
1,07,000 \text { ) }\end{array}$ & $\begin{array}{l}2 \\
102 \\
16\end{array}$ & $\begin{array}{l}1.67 \\
85.00 \\
13.33\end{array}$ & 60741.66 & 46337.39 \\
\hline 9 & $\begin{array}{l}\text { Risk } \\
\text { Orientation }\end{array}$ & $\begin{array}{l}\text { Low } \\
\text { Medium } \\
\text { High }\end{array}$ & $\begin{array}{l}51 \\
62 \\
7\end{array}$ & $\begin{array}{l}42.50 \\
51.67 \\
5.83\end{array}$ & 16.71 & 2.22 \\
\hline
\end{tabular}


Table.2 Distribution of the respondents on the basis of the combination of pesticides used

\begin{tabular}{|c|c|c|c|}
\hline Sl. No. & No. of combinations & No. of respondents $\mathbf{( N = 1 2 0})$ & Percentage \\
\hline $\mathbf{1 .}$ & No combination & 29 & 24.17 \\
\hline $\mathbf{2 .}$ & Two-three insecticides along with fungicides & 66 & 55.00 \\
\hline $\mathbf{3 .}$ & Combine any two pesticides and used & 25 & 20.83 \\
\hline & Total & $\mathbf{1 2 0}$ & $\mathbf{1 0 0}$ \\
\hline
\end{tabular}

Table.3 Distribution of the respondents on the basis of classification of pesticides used based on mode of action

\begin{tabular}{|c|l|c|c|}
\hline Sl. No. & \multicolumn{1}{|c|}{ Based on mode of action } & $\begin{array}{c}\text { No. of respondents } \\
(\mathbf{N = 1 2 0})\end{array}$ & Percentage \\
\hline $\mathbf{1 .}$ & Systemic + Contact & 76 & 63.33 \\
\hline $\mathbf{2 .}$ & Systemic & 31 & 25.83 \\
\hline $\mathbf{3}$. & Contact & 13 & 10.84 \\
\hline & Total & $\mathbf{1 2 0}$ & $\mathbf{1 0 0}$ \\
\hline
\end{tabular}

Table.4 Preferences of pesticides by respondents

\begin{tabular}{|c|c|c|}
\hline SI.No & Pesticides & Rank \\
\hline $\mathbf{A}$ & Herbicides & \\
\hline 1. & Pyrazosulfuron ethyl & I \\
\hline 2. & 2, 4-D & II \\
\hline 3. & Metsulfuronmethyl+Chlorimuron ethyl & III \\
\hline 4. & Pretilachlor & IV \\
\hline 5. & Bispyribac sodium & $\mathrm{V}$ \\
\hline 6. & Butachlor & VI \\
\hline 7. & Penoxsulam & VII \\
\hline 8. & Fenoxaprop-p-ethyl & VIII \\
\hline B & Insecticides & \\
\hline 1. & Chlorantraniliprole & I \\
\hline 2. & Dichlorvos & II \\
\hline 3. & Lambda-cyhalothrin & III \\
\hline 4. & Imidacloprid & IV \\
\hline 5. & Phorate & V \\
\hline 6. & Thiamethoxam & VI \\
\hline 7. & Fipronil & VII \\
\hline 8. & Chlorpyriphos & VIII \\
\hline 9. & Quinalphos & IX \\
\hline 10. & Carbofuran & $\mathrm{X}$ \\
\hline 11. & Acetamiprid & $\mathrm{XI}$ \\
\hline $\mathbf{C}$ & Fungicides & \\
\hline 1. & Carbendazim & I \\
\hline 2. & Propiconazole & II \\
\hline 3. & Tricyclazole & III \\
\hline 4. & Hexaconazole & IV \\
\hline 5. & Captan & V \\
\hline 6. & Copper oxychloride & VI \\
\hline 7. & Copper hydroxide & VII \\
\hline
\end{tabular}


From Table 4 it was revealed that among herbicides Pyrazosulfuron ethyl was ranked first by the respondents, followed by $2,4-\mathrm{D}$, Metsulfuron methyl+Chlorimuron ethyl, Pretilachlor, Bispyribac sodium, Butachlor, Penoxsulam and Fenoxaprop-p-ethyl.It also showed that among the insecticides, Chlorantraniliprole was ranked first by the respondents, followed by Dichlorvos, Lambda-cyhalothrin, Imidacloprid, Phorate, Thiamethoxam, Fipronil, Chlorpyriphos, Quinalphos, Carbofuran and Acetamiprid. Further it was observed that among fungicides, Carbendazim was ranked first by the respondents, followed by Propiconazole, Tricyclazole, Hexaconazole, Captan, Copper oxychloride and Copper hydroxide.

\section{Acknowledgement}

The authors are thankful to the Pandit Deen Dayal Upadhyay Institute of Agricultural Sciences, Utlou, Bishnupur, Manipur for providing all the facilities, kind cooperation and constructive suggestions during the course of investigation. The author offers his grateful acknowledgement to the official staffs of KVKThoubal, KVK Bishnupur and Central Agricultural University, Imphal, Manipur for their valuable time and effort in meticulously providing valuable information for the study within the specified time given.

\section{References}

Agricultural statistics at a glance, (2018).Government of India.

Banerjee, I., Tripathi, S.K., Roy, A.S. and Sengupta, P. (2014). Pesticides use pattern among farmers in a rural district of West Bengal, India. Journal of Natural Science, Biology and Medicine, 5(2): 313-316.

Brar, G.S., Patyal, S.K., Dubey, J.K. and Singh, G. (2018). Survey on pesticide use pattern and farmers perceptions in cauliflower and brinjal growing areas in three districts of Himachal Pradesh, India. International Journal of Current Microbiology and Applied Sciences, 7(3): 2417-2423.

Devi, P. I., Thomas, J. and Raju, R. K. (2017). Pesticide consumption in India: A spatiotemporal analysis. Agricultural Economics Research Review, 30(1): 163-172.

Iwuchukwu, J.C., Nwobodo, C.E. and Udoye, C.E. (2017). Problems and prospects of pineapple production in Enugu state, Nigeria. Journal of Agricultural Extension, 21(1): 167-180.

Landage, N.N. (2015). Utilization pattern and extent of use of pesticides by brinjal growers. M.sc. Thesis. Mahatma Phule Krishi Vidyapeeth, Rahuri, Maharastra, India.

Meenambigai, C., Bhuvaneswari, K., Kumar, K. M. and Sangavi, R. (2017). Pesticides usage pattern of okra, Abelmoschus esculentus (L) Moench in Tamil Nadu. Journal of Entomology and Zoology Studies, 5(6): 1760-1765.

Pareek, U. and Trivedi, G. (1965). Factor analysis of socio-economic status of farmers in India. Rural Sociology,30(2): 311-321.

Singh. P.K. and Varshney, J.G. (2010). Adoption level and constraints in rice production technology. Indian Research Journal of Extension Education, 10(1): 91-94.

Supe, S.V. (1969). Factors related to different degrees of rationality in decision making among the farmers in Buldana district. (Unpublished) Ph.D. Thesis. IARI, New Delhi.

Zore, G.T., Deshmukh, A.N., Mokhale, S.U. and Pingale, S.S. (2017). Knowledge and adoption of recommended practices of brinjal. International Journal of Agricultural Sciences, 13 (1): 34-37. 
How to cite this article:

Arnold Meitankeisangbam, Aheibam Tarajit Singh and Changamayum Girija Devi. 2020. Utilization Pattern of Pesticides by Rice Growers in Thoubal District, Manipur. Int.J.Curr.Microbiol.App.Sci. 9(10): 3027-3033. doi: https://doi.org/10.20546/ijcmas.2020.910.364 